\title{
Minimum Water Requirements of Four Turfgrasses in the Transition Zone
}

\author{
Jinmin Fu, ${ }^{1}$ Jack Fry, ${ }^{2}$ and Bingru Huang ${ }^{3}$ \\ Department of Horticulture, Forestry and Recreation Resources, Kansas State \\ University, Manhattan, KS 66506
}

Additional index words. Cyndon dactylon $\times$ C. transvaalensis, drought, evapotranspiration, Festuca arundinacea, irrigation, Poa pratensis, Zoysia japonica

\begin{abstract}
Water requirements for 'Meyer' zoysiagrass (Zoysia japonica Steud., hereafter referred to as zoysia), 'Midlawn' bermudagrass [Cynodon dactylon (L.) Pers. $\times$ C. transvaalensis Burtt-Davy, hereafter referred to as bermuda], 'Falcon II' tall fescue (Festuca arundinacea Schreb.) and 'Brilliant'kentucky bluegrass (Poapratensis L., hereafter referred to as bluegrass) were evaluated under a mobile rainout shelter at deficit irrigation levels of $20 \%$ to $100 \%$ of actual evapotranspiration (ET), applied twice weekly, between June and September 2001 and 2002. Soil was a river-deposited silt loam (fine, montmorillonitic, mesic Aquic Arquidolls). Minimum annual irrigation amounts required to maintain quality ranged from $\mathbf{2 4 4} \mathbf{~ m m}$ for bermuda to $552 \mathrm{~mm}$ for bluegrass. Turfgrass species and respective irrigation levels (\% of $\mathrm{ET}_{\mathrm{a}}$ ) at which season-long acceptable turf quality was maintained in each year were bluegrass, $100 \%$ (evaluated 2001 only); tall fescue, $60 \%$ in 2001 and $80 \%$ in 2002 ; bermuda, $60 \%$ in both years; and zoysia, $80 \%$ in both years. A landscape manager who could tolerate one week of less- than-acceptable quality could have irrigated tall fescue at $40 \% \mathrm{ET}_{\mathrm{a}}(224 \mathrm{~mm})$ in 2001 and $60 \%$ ET ( $359 \mathrm{~mm})$ in 2002. Likewise, bermuda exhibited unacceptable quality on only one September rating date when irrigated at $40 \% \mathrm{ET}_{\mathrm{a}}(163 \mathrm{~mm})$ in 2001 . Bermuda was able to tolerate a lower leaf relative water content (LRWC) and higher level of leaf electrolyte leakage (EL) compared to other grasses before quality declined to an unacceptable level.
\end{abstract}

Turfgrass water use rates often exceed natural precipitation, and during extended periods without rainfall, restrictions may be imposed limiting water that can be applied to turf areas. As such, researchers have sought to identify turf species and cultivars that have good drought resistance (Aronson et al., 1987; Carrow, 1995; Fry and Butler, 1989), and irrigation management techniques to reduce water inputs. Some grasses, such as bermuda and tall fescue, have deep root systems that help them avoid drought when precipitation is limited (Qian et al., 1996). Others, such as zoysia, have shallower root systems, but tolerate drought using osmotic adjustment and other physiological mechanisms (Qian and Fry, 1997)

Over the past 20 years, several researchers have addressed the subject of deficit irrigation, returning water in amounts less than $\mathrm{ET}_{\mathrm{a}}$, as a water conservation technique (Feldhake et al., 1984; Fry and Butler, 1989; Qian and Engelke, 1999). Turf managers overseeing installation of new golf courses, housing developments, and other turf areas are commonly queried by government administrators as to how much irrigation water will be required to maintain an acceptable quality turf in the landscape. However, the amount of water required to maintain

Received for publication 9 Mar. 2004. Accepted for publication 24 Apr. 2004. Thanks are extended to Turf Producers International and the Kansas Turfgrass Foundation for supporting this project. Submitted as contribution number 04-309-J of the Kansas Agricultural Experiment Station.

${ }^{1}$ Former graduate assistant. Currently research associate, Department of Horticulture and Landscape Architecture, Colorado State Univ., Fort Collins, CO 80523

${ }^{2}$ Professor

${ }^{3}$ Associate professor, Department of Plant Science, Rutgers Univ., New Brunswick, NJ 08901. acceptable quality of various turfgrass species throughout the growing season in the transition zone, a loosely defined region between temperate and subtropical climates, has not been determined.

'Rebel' tall fescue and 'Merion' bluegrass visual quality were reduced by about $10 \%$ when irrigated at a 27\% ET deficit in Colorado (Feldhake et al., 1984). In another Colorado test, tall fescue watered every $2 \mathrm{~d}$ at $50 \%$ ET exhibited only small reductions in turf quality (Fry and Butler, 1989). Qian and Engelke (1999) observed that irrigation required to maintain acceptable turf quality ranged from about $35 \%$ of evaporation from a class A pan ( $\left.\mathrm{E}_{\mathrm{pan}}\right)$ for 'Tifway' bermuda to $67 \% \mathrm{E}$ for 'Rebel II' tall fescue. Gibeault et al. (1985) reported that turf quality in blends of bluegrass and perennial ryegrass (Lolium perenne L.) cultivars, and 'Kentucky31' tall fescue, declined slightly when irrigation was reduced by $20 \%$ of calculated ET in southern California. Tall fescue and bermuda irrigated $4 \mathrm{~d}$ weekly in Nevada required $80 \%$ and $60 \%$, respectively, of calculated referenceET to maintain cover and color (Dean et al., 1996).

Previous evaluations of turfgrass response to deficit irrigation considered turf quality without regard to plant physiological responses. A better understanding is needed of how turfgrasses respond physiologically to deficit irrigation. For example, LRWC, an indicator of leaf water status, decreases as drought stress progresses. Drought stress also causes cellular membrane modification, and increases EL (Kirnak et al., 2001); the degree of leakage can be measured and is a good indicator of leaf cell damage during progressive stress (Huang and Fu, 2001). The objective of this study was to determine minimum water required to maintain acceptable visual quality, and deficit irrigation effects on
LRWC and EL of zoysia, bermuda, tall fescue, and bluegrass in the transition zone.

\section{Materials and Methods}

Growing conditions and treatments. This experiment was conducted using an automated, mobilerainout shelter $\left(180 \mathrm{~m}^{2}\right)$ at the Rocky Ford Turfgrass Research Centerat Manhattan, Kans., from 4 June to 14 Sept. 2001 and from 3 June to 13 Sept. 2002. The shelter was essentially a small building constructed of wood, with an A-frame roof and metal siding. During dry weather, the shelter rested just to the north of the study area. The shelter was triggered by a minimum of 0.38 $\mathrm{mm}$ precipitation, and required about $2 \mathrm{~min}$ to move south on rails and completely cover the test area. One hour after precipitation ceased, the shelter returned to its resting position. Mean maximum air temperatures during each month of the study (2001 and 2002, respectively) were June, 27.8 and $31.1{ }^{\circ} \mathrm{C}$; July, 34.4 and $35^{\circ} \mathrm{C}$; August, 32.8 and $32.8^{\circ} \mathrm{C}$; and September, 28.9 and $32.8^{\circ} \mathrm{C}$. Mean minimum air temperatures for each month of the study (2001 and 2002, respectively) were June, 16.1 and $17.8^{\circ} \mathrm{C}$; July, 21.1 and $20^{\circ} \mathrm{C}$; August, 18.3 and $18.6^{\circ} \mathrm{C}$; and September, 14.4 and $17.2^{\circ} \mathrm{C}$.

The experimental design was a split-plot, with turfgrass species as the whole plot and irrigation level as the sub-plots. Whole plots measured 5.9x $1.8 \mathrm{~m}$, and consisted of 'Meyer' zoysia, 'Midlawn' bermuda, 'Falcon II' tall fescue, and 'Brilliant' bluegrass. All whole plots were established by sodding in spring, 2000 on a river-deposited silt loam soil, with a pH 6.4 and $\mathrm{P}$ and $\mathrm{K}$ levels of 41 and $367 \mathrm{mg} \cdot \mathrm{kg}^{-1}$, respectively. Subplots measured $1.2 \times 1.8 \mathrm{~m}$, and consisted of irrigation levels of $20 \%, 40 \%, 60 \%, 80 \%$, and $100 \%$ of ET Each plot was bordered by metal edging (set $15-\mathrm{cm}$ deep) to minimize lateral movement of water upon application.

Water was applied twice weekly using a metered, hand-held hose with a fan spray nozzle attached. Deficit irrigation amounts were determined by taking the fraction of water use of lysimeter-grown turf receiving $100 \% \mathrm{ET}$. Pots $(10.1 \mathrm{~cm}$ in diameter and $25 \mathrm{~cm}$ deep) constructed of PVC were planted with turf sampled in April 2001 using a 10.1-cm-diameter cup cutter to remove a $25-\mathrm{cm}$ deep, intact soil core and accompanying turf. Cores were then placed into the pots to create lysimeters. Each lysimeter had a nylon screen on the bottom end that was fastened with duct tape.

After planting, lysimeters were placed in holes that had been dug in the center of each sub-plot scheduled to receive $100 \%$ ET . Turf in lysimeters was maintained identically to that of the surrounding fetch.

The day before the study began each year, lysimeters were soaked until water was draining through the bottom of each. When drainage had ceased, each was sealed on the bottom end with a plastic bag, weighed to determine its reference mass, and returned to respective holes in the plot area. Evapotranspiration was measured using the water balance method described by Qian et al. (1996).

Deficitirrigation amounts for field plots were calculated as deficit irrigation level $\times \mathrm{ET}_{\mathrm{a}} \times$ an 
Table 1. Evapotranspiration rates of four turfgrass species, and minimum irrigation amounts required to maintain season-long quality in 2001 and 2002.

\begin{tabular}{llccc}
\hline & & \multicolumn{2}{c}{$\mathrm{ET}_{\mathrm{a}}(\mathrm{mm})$} & \multicolumn{2}{c}{$\begin{array}{c}\text { Min water } \\
\text { Year }\end{array}$} & Species & Daily $^{\mathrm{z}}$ & Total $^{\mathrm{y}}$ & ${\text { required }(\mathrm{mm})^{\mathrm{x}}}^{2}$ & $552 \mathrm{a}$ & 552 \\
2001 & Kentucky bluegrass & $5.6 \mathrm{a}$ & $562 \mathrm{a}$ & 337 \\
& Tall fescue & $5.7 \mathrm{a}$ & $407 \mathrm{~b}$ & 244 \\
& Bermudagrass & $4.1 \mathrm{~b}$ & $390 \mathrm{~b}$ & 312 \\
& Zoysiagrass & $3.9 \mathrm{~b}$ & $598 \mathrm{a}$ & 478 \\
& Tall fescue & $5.9 \mathrm{a}$ & $412 \mathrm{~b}$ & 247 \\
& Bermuda & $4.0 \mathrm{~b}$ & $449 \mathrm{~b}$ & 359 \\
\hline
\end{tabular}

${ }^{2}$ Daily averages represent a mean of 27 dates from 4 June to 14 Sept. 2001 and from 3 June to 13 Sept. 2002.

yTotal ET from 4 June 4 to 14 Sept. 2001 and from 3 June to 13 Sept. 2002.

${ }^{x}$ Minimum total amount of water required to maintain acceptable quality between 4 June and 14 September, 2001 and 3 June and 13 Sept. 2002.

${ }^{\text {w}}$ Means followed by the same letters within a column and year are not significantly different $(P<0.05)$.

area adjustment factor. Total water applied to turf receiving $100 \% \mathrm{ET}_{\mathrm{a}}$ during the study period in 2001 and 2002 was equivalent to ET rates presented in Table 1. Severe decline of bluegrass in 2002 precluded data collection. This was due to a combination of high bluegrass billbug (Sphenophorus parvulus Gyllenhal) populations and high temperatures.

Turf was mowed twice weekly at 5 to $6 \mathrm{~cm}$ using a walk-behind rotary mower, and clippings were collected. Nitrogen from urea was applied at $49 \mathrm{~kg} \cdot \mathrm{ha}^{-1}$ to tall fescue and bluegrass on 3 May, 19 Sept., and 8 Nov. 2001; and 3 May, 18 Sept., and 15 Nov. 2002. Zoysia and bermuda received an equivalent level of $\mathrm{N}$ on 3 May and 29 June 2001 and 3 May and 5 Aug. 2002.

After the 2001 study period, the study area was exposed to natural precipitation until the study began the following June. Lysimeters were left in the field throughout this period as well. The plot area was thoroughly irrigated to bring the soil to field capacity prior to beginning irrigation treatments in 2002.

Data collection and analysis. Data were collected on ET, turf quality, LRWC, and EL. Evapotranspiration rate was determined twice weekly by measuring change in mass of lysimeters using the water balance method described previously.

Turf quality was rated visually once weekly using a 0 to 9 scale where $0=$ brown, dead turf and $9=$ optimum color, density, and uniformity. Turf receiving a rating of 6 was deemed to have acceptable quality for a home lawn.

Leaves measuring $\approx 10 \mathrm{~mm}$ long and to provide $\approx 1.0 \mathrm{~g}$ fresh weight were sampled randomly at two locations in each plot in order to measure LRWC, calculated as LRWC $=(\mathrm{FW}-\mathrm{DW}) \times$ 100/(TW - DW), where FW is leaf fresh weight, DW is leaf dry weight after drying for at least
$48 \mathrm{~h}$ at $80^{\circ} \mathrm{C}$, and TW is the weight of leaves at full turgor after soaking in water for $24 \mathrm{~h}$ at room temperature $\left(22^{\circ} \mathrm{C}\right)$ (Fu and Huang, 2001).

Leaf EL was determined by taking a $1.0 \mathrm{~g}$ sample of leaves from two locations in each subplot, rinsing with water, immersing in 20 $\mathrm{mL}$ deionized water, and subjecting to a vacuum of $48 \mathrm{kPa}$ for $15 \mathrm{~min}$ (Huang and $\mathrm{Fu}, 2001$ ). Samples were then shaken in flasks containing deionized water on a shaker table (Lab-Line Instruments, Inc., Melrose Park, IL) for $24 \mathrm{~h}$. The conductivity of the solution $\left(\mathrm{C}_{\text {initial }}\right)$ with fresh tissues was measured using a conductivity meter (model 32; YSI, Yellow Spring, Ohio). Leaves then were killed by autoclaving at $140^{\circ} \mathrm{C}$ for 20 min, and the conductivity of the solution with killed tissues $\left(\mathrm{C}_{\max }\right)$ was measured after soaking another $24 \mathrm{~h}$. Relative EL was calculated as $\left(\mathrm{C}_{\text {initial }} / \mathrm{C}_{\max }\right) \times 100$.

Treatment effects were determined by analysis of variance according to the mixed procedure of Statistical Analysis System (SAS Institute Inc., 1989). Variation was partitioned into grass species, deficit irrigation level, and treatment duration (sampling time). Analyses showed a significant difference in the corresponding interaction between grass species and deficit irrigation level. Therefore, the comparison of deficit irrigation treatments within a grass species was statistically analyzed. Differences among treatment means within a species were separated by a least significant difference mean separation test $(P<0.05)$. Multiple linear regression was used to determine the critical values of LRWC and EL below which unacceptable turf quality was observed. Initial data collected were considered as covariants to analyze covariance effects
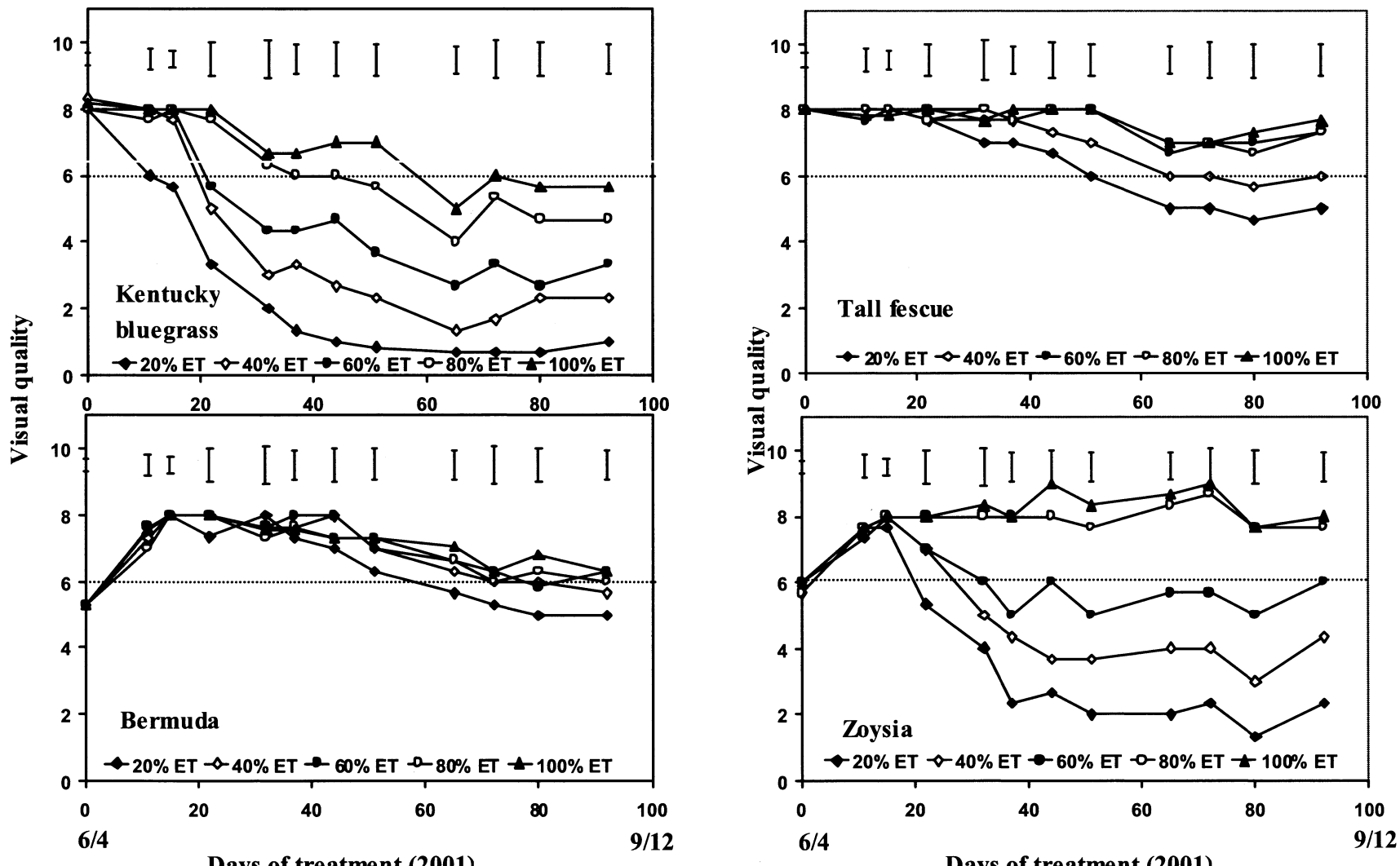

Fig. 1. Visual quality of bluegrass, tall fescue, bermuda, and zoysia in response to deficit irrigation in 2001. Quality was rated on a 0 to 9 scale, $9=$ best. A rating of 6 was deemed acceptable for a home lawn. Bars represent LSD values $(P<0.05)$. The horizontal line at a quality rating of 6 denotes the minimum acceptable quality. 


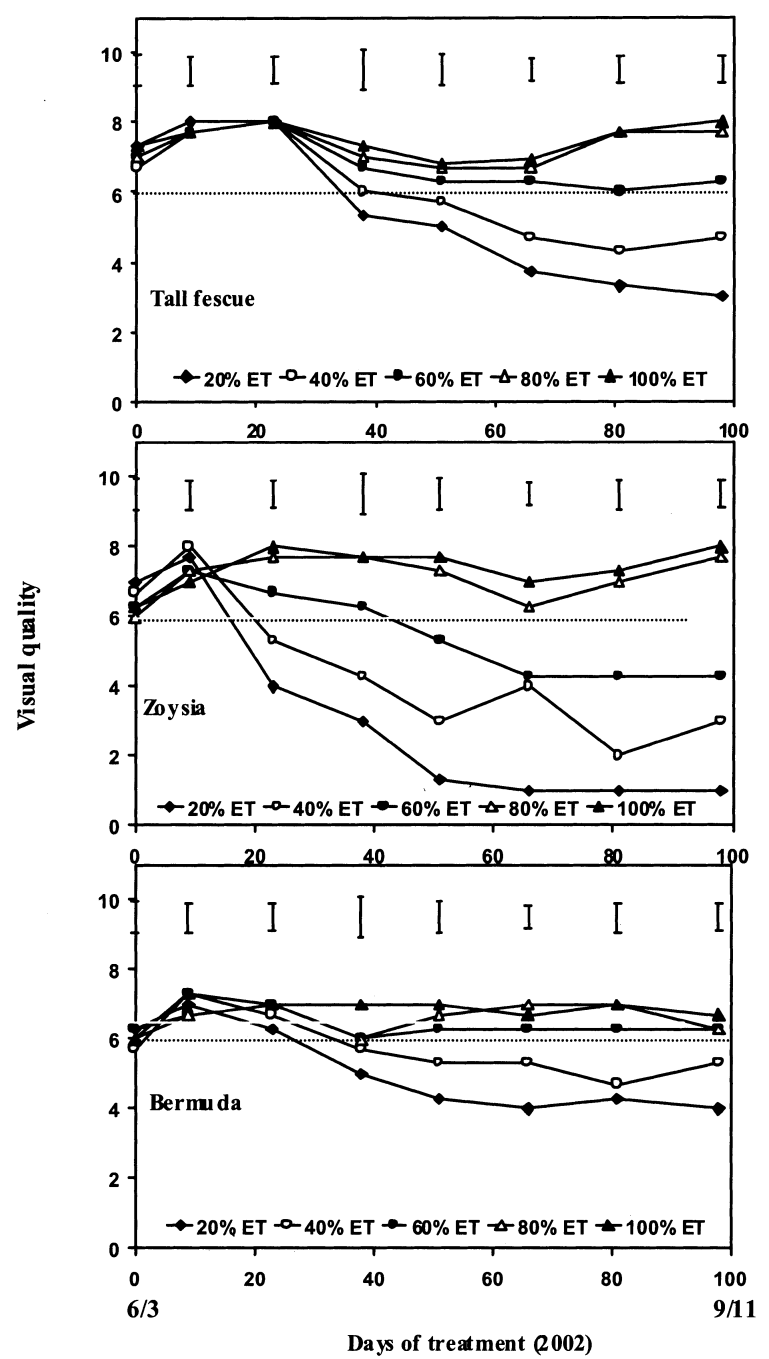

Fig. 2 Visual quality of tall fescue, bermuda, and zoysia in response to deficit irrigation in 2002. Quality was rated on a 0 to 9 scale, $9=$ best. A rating of 6 was deemed acceptable for a home lawn. Bars represent LSD values $(P<0.05)$. The horizontal line at a quality rating of 6 denotes the minimum acceptable quality.

according to the general linear models procedure of the Statistical Analysis System (SAS Institute Inc., 1989). This allowed values for each species to be adjusted as if each treatment had the same initial value.

\section{Results and Discussion}

Evapotranspiration. Bluegrass and tall fescue had similar ET rates in 2001, which were higher than those of bermuda and zoysia (Table 1). In 2002 , tall fescue ET was higher than that of bermuda and zoysia. Mustang tall fescue ET was also reported to be higher than that of 'Midlawn' bermuda and 'Meyer' zoysia in an earlier Kansas test (Qian et al, 1996). However, zoysia exhibited higher ET than bermuda during each year of that test. Discrepancies between results may have been due to different methods used in lysimeter construction. Qian et al. (1996) used a larger (25-cm-diameter) lysimeter, and a calcined clay soil mix; whereas, we used a 10.1-cm-diameter lysimeter and undisturbed field soil.

Minimum water requirements and turf quality. Turfgrass species and respective irrigation levels (\% of ET $)$ at which season-long acceptable turf quality was maintained in each year were: bluegrass, $100 \%$ (evaluated 2001 only); tall fescue, $60 \%$ in 2001 and $80 \%$ in 2002; bermuda, $60 \%$ in both years; and zoysia, $80 \%$ in both years (Figs. 1 and 2). In 2001, minimum irrigation amounts required to maintain acceptable quality for the 102-d study period ranged from $244 \mathrm{~mm}$ for bermuda to $552 \mathrm{~mm}$ for bluegrass (Table 1). In 2002, irrigation amounts required to maintain quality ranged from $247 \mathrm{~mm}$ for bermuda to $478 \mathrm{~mm}$ for tall fescue.

Bluegrass and zoysia were most sensitive to deficit irrigation as reflected by the range of quality scores across treatments in 2001 (Fig. 1). Quality of tall fescue irrigated at 40\% ET fell below the acceptable level on only one rating date in 2001 (Fig. 1). Likewise, in 2002, quality of tall fescue was below an acceptable level on only one date at $60 \%$ ET (Fig. 2). Hence, a landscape manager that could tolerate a slightly reduced level of quality for a short period could have done so with tall fescue and irrigation levels of $40 \% \mathrm{ET}_{\mathrm{a}}$ (224 mm of water) in 2001 or $60 \% \mathrm{ET}_{\mathrm{a}}$ (359 mm of water) in 2002. Using these values, minimum water required to maintain tall fescue would have been substantially less than that for zoysia in 2001 ( $224 \mathrm{vs} .312 \mathrm{~mm}$ ) and equivalent to zoysia in 2002 (359 $\mathrm{mm}$ ) (Table 1).

Quality of bermuda receiving 40 to $100 \%$ ET did not differ greatly through much of the 2001 season (Fig. 1). A landscape manager

Fig. 3. Leaf relative water content of bluegrass, tall fescue, bermuda, and zoysia in response to deficit irrigation in 2001. Bars represent LSD values $(P<0.05)$.

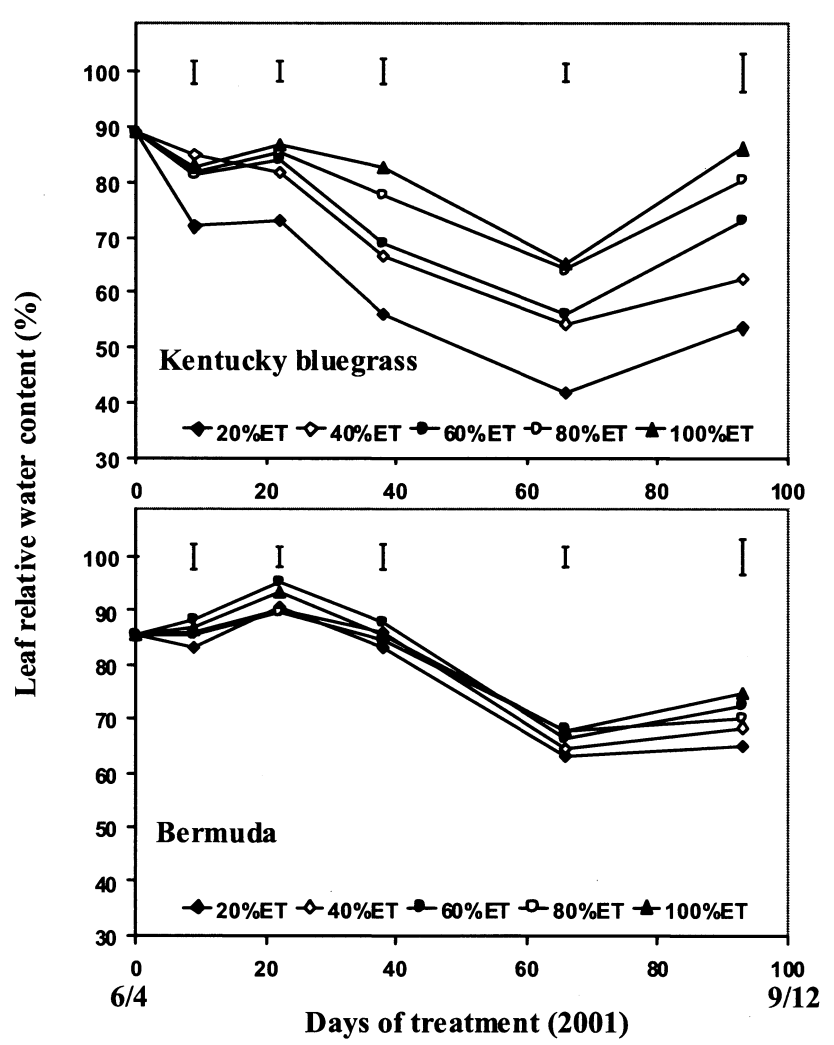

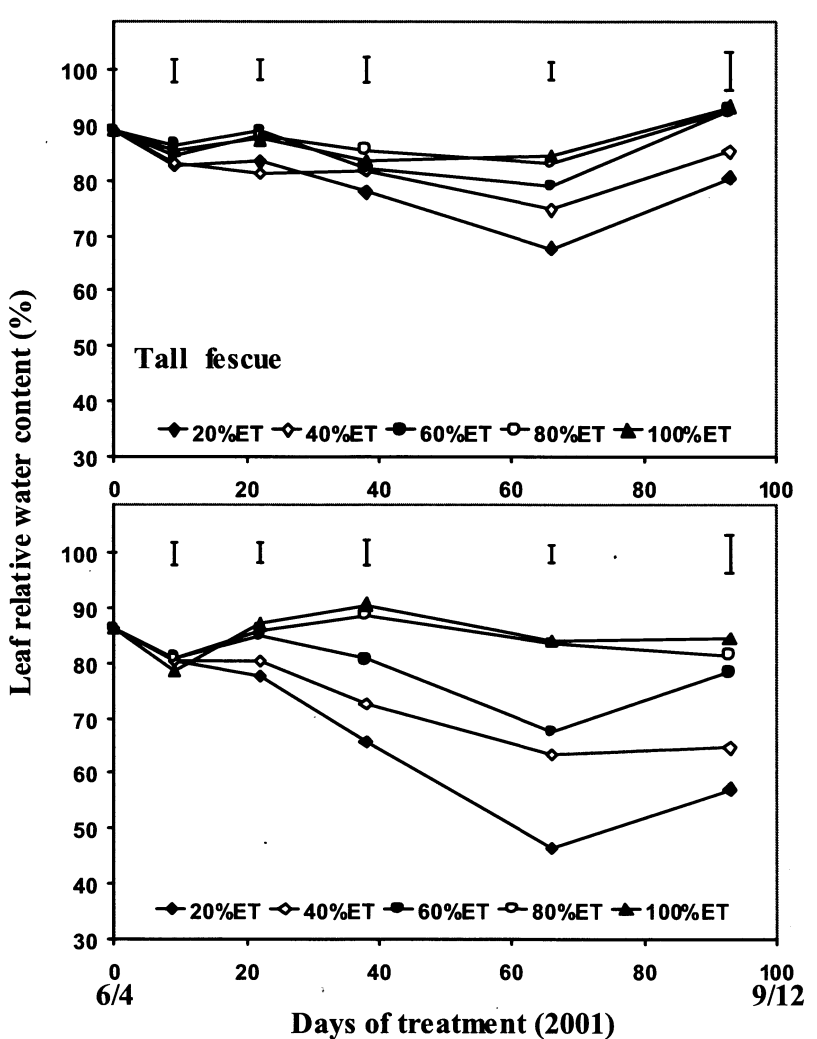

HortScience Vol. 39(7) December 2004 

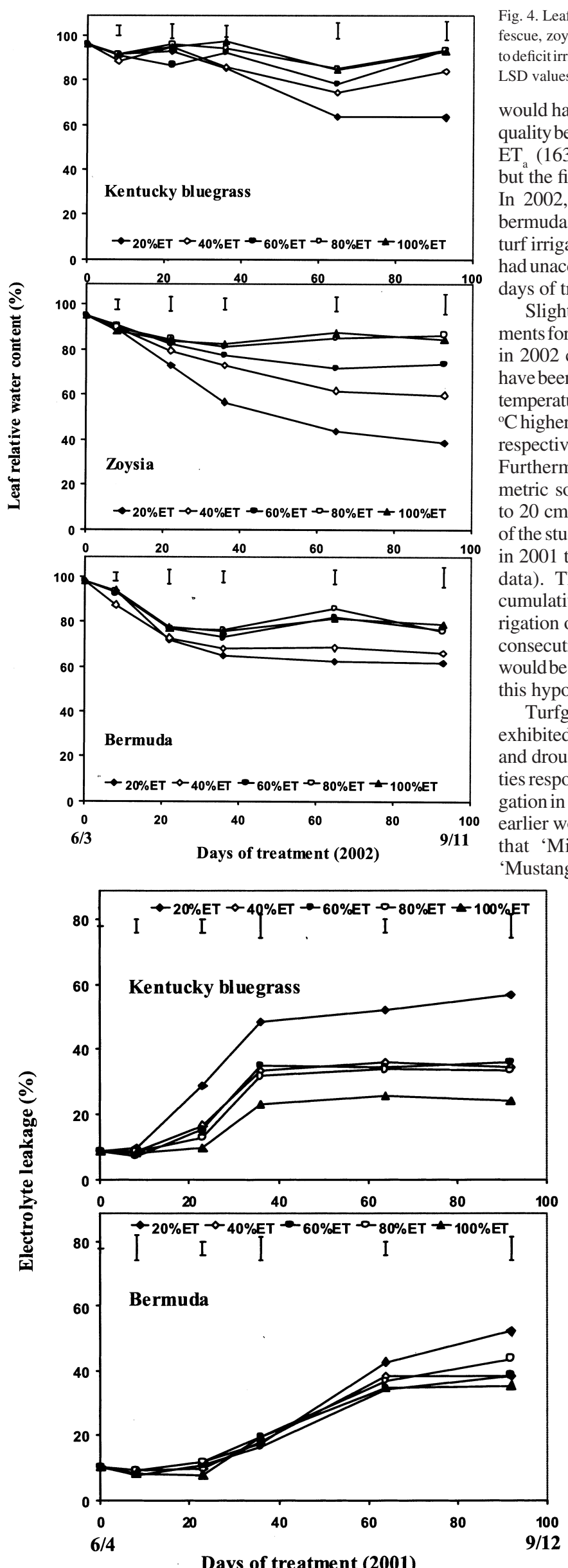

Fig. 4. Leaf relative water content of tall fescue, zoysia, and bermuda in response to deficit irrigation in 2002. Bars represent LSD values $(P<0.05)$.

would have observed acceptable quality bermuda by applying $40 \%$ ET (163 $\mathrm{mm}$ of water) on all but the final rating date in 2001 . In 2002, greater differences in bermuda quality occurred, and turf irrigated at $20 \%$ or $40 \%$ ET had unacceptable quality after 20 days of treatment (Fig. 2).

Slightly higher water requirements for tall fescue and bermuda in 2002 compared to 2001 may have been due to average daytime temperatures that were 2.3 and 3.9 ${ }^{\circ} \mathrm{C}$ higher in June and September, respectively, in 2002 than 2001. Furthermore, the initial volumetric soil water content at a 0 to $20 \mathrm{~cm}$ depth at the beginning of the study was about $5 \%$ higher in 2001 than 2002 (unpublished data). There could also be a cumulative effect of deficit irrigation on turfgrass response in consecutive years; longer studies would be needed confirm or refute this hypothesis.

Turfgrass species that have exhibited deep rooting potential and drought avoidance capabilities responded well to deficit irrigation in this study. For example, earlier work in Kansas indicated that 'Midlawn' bermuda and 'Mustang' tall fescue had greater ability than 'Meyer' zoysia to root deeply in the soil profile, particularly at a 60 to $90 \mathrm{~cm}$ depth (Qian et al., 1997). Similarly, bluegrass has been shown to have a relatively shallow root system compared to tall fescue (Sheffer et al., 1987). In this test, it seems that grasses that had the greatest potential to root deeply also responded most positively to deficit irrigation. The shallower rooted species, zoysia and bluegrass, exhibited quality decline as the levels of irrigation applied were not sufficient to sustain quality. Perhaps deep rooting allowed bermuda and tall fescue to make use of water deep in the profile, which contributed to their superior performance when subjected to deficit irrigation.

Turfgrasses and their respective ranges for water requirements in Dallas, Texas, based on irrigation applied every $3 \mathrm{~d}$ using a Class A evaporation pan $\left(\mathrm{E}_{\text {pan }}\right)$, were 'Tifway' bermuda, $12 \%$ to $35 \%$; 'Meyer' zoysia, $39 \%$ to $68 \%$; and 'Rebel II' tall fescue, 49\% to 67\% (Qian and Engelke, 1999). On rating dates when differences among species were observed, bermuda generally performed better under lower deficit irrigation levels than 'Meyer' or 'Rebel II'. Bermuda irrigated at the first indication of wilt in Arizona required $57 \%$ to $64 \%$ of reference ET to maintain quality (Garrot and Mancino, 1994).

When irrigated at $50 \%$ ET every $2 \mathrm{~d}$ in Colorado, only small reductions in tall fescue quality were observed (Fry and Butler, 1989). In another Colorado study, using a 3-d irrigation interval, acceptable tall fescue quality was maintained by irrigating with a level of water equivalent to $60 \%$ of Penman reference ET (Ervin and Koski, 1998). Average water

Fig. 5. Electrolyte leakage of bluegrass, tall fescue, bermuda, and zoysia in response to deficit irrigation in 2001. Bars represent LSD values $(P<0.05)$.

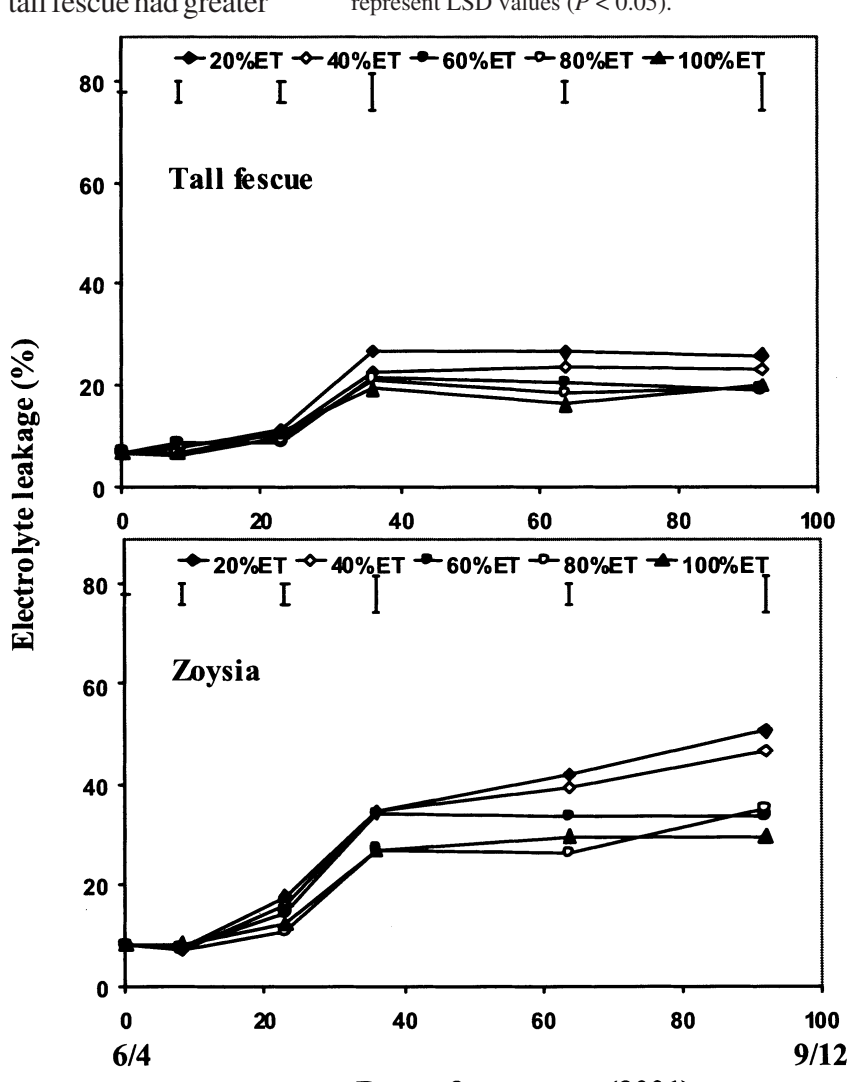




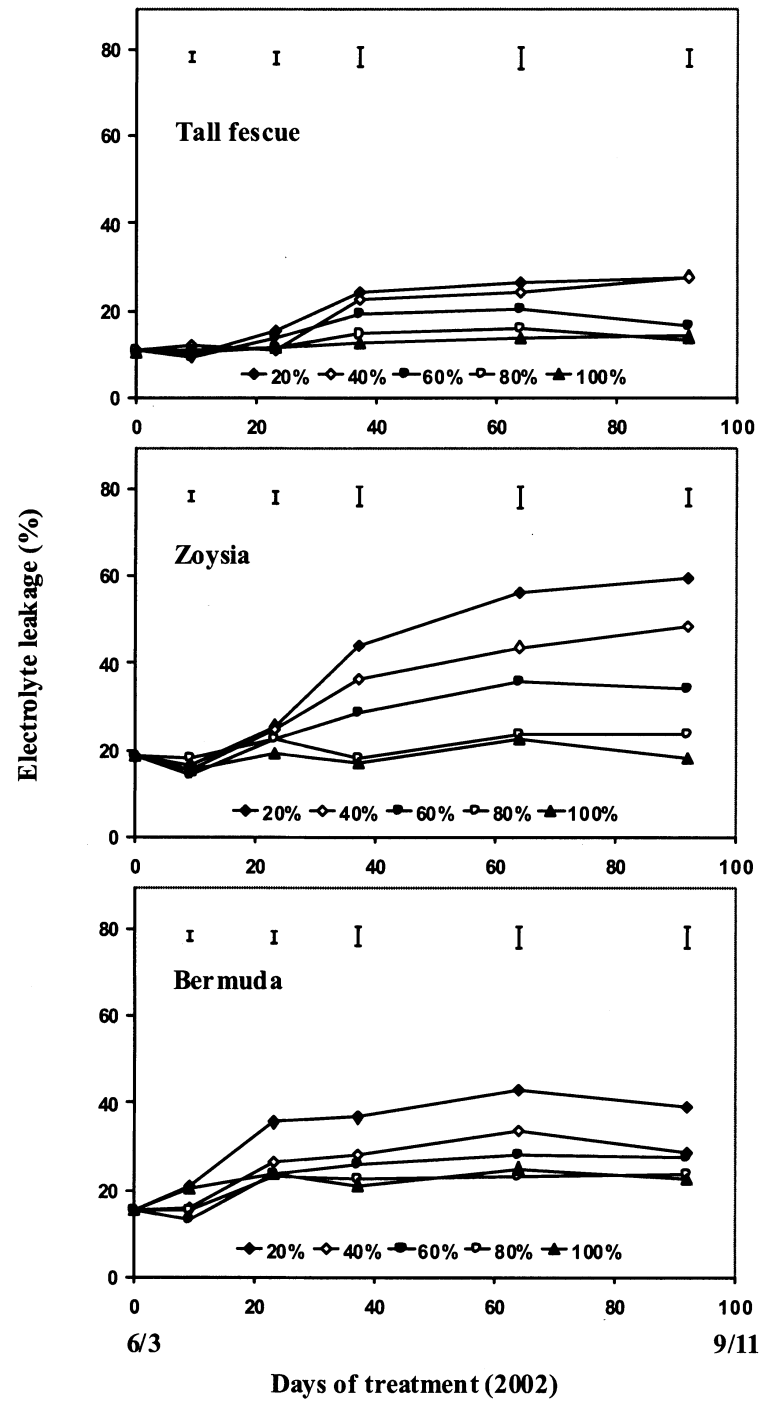

requirements of turfgrasses in Georgia, based uponE $\mathrm{p}_{\mathrm{pan}}$, were 'Tifway' bermuda, 66\%, 'Meyer' zoysia, $80 \%$, and 'Rebel II' tall fescue, $78 \%$. (Carrow, 1995).

Comparison of minimum turf water requirements among studies is difficult, for some use $\mathrm{E}_{\mathrm{pan}}$ as a reference (Carrow, 1995; Qian et al, 1999), some use empirical models (Ervin and Koski, 1998; Garrot and Mancino, 1994), and others use ET (Fry and Butler, 1989; and the present study) to guide irrigation levels. However, some work has been done that may allow comparison of results from studies using deficit irrigation based onET and $_{\mathrm{pan}}$. Qian etal. (1996) comparedET to evaporation pan values over 2 years in Manhattan, Kans. Using the equations generated in that work, it is possible to take the average $\mathrm{ET}_{\mathrm{a}}$ values measured in this study (Table 1) and determine $\mathrm{E}_{\mathrm{pan}}$. In so doing, turf irrigation requirements reported as $\mathrm{E}_{\mathrm{pan}}$ can be divided by the following to determine $\mathrm{ET}$ for the respective grasses: bermuda, 1.31; zoysia, 1.0 ; and tall fescue 0.97 .

Using these coefficients to compare our results with others, irrigation requirements for zoysia reported herein are the same as those reported in Georgia (Carrow, 1995). Bermuda irrigation requirements in our test in 2001 fell within the range of values reported in Texas (Qian and Engelke, 1999) in 2001, but were
Fig. 6. Electrolyte leakage of tall fescue, zoysia, and bermuda in response to deficit irrigation in 2002. Bars represent LSD values $(P<0.05)$

higher than those from Texas and Georgia (Carrow, 1995) in 2002. Tall fescue irrigation requirements in 2001 were lower than those cited for either Georgia or Texas, but in 2002 were comparable to those reported in Georgia. Differences among locations in turfgrass irrigation requirements are likely the result of differences in rating methods researchers use to evaluate minimum acceptable quality or general stand upkeep, soil types, irrigation frequencies, weather conditions, and the length of growing seasons.

Leaf relative water content and electrolyte leakage. Changes in LRWC in all turfgrasses during both study periods is presented in Figs. 3 and 4. The present study indicated that turf quality was acceptable until LRWC dropped to $76 \%$ for bluegrass, $77 \%$ for tall fescue, $65 \%$ for bermuda, and $76 \%$ for zoysia $\left(R^{2}\right.$ ranging from 0.80 to 0.99 in 2001 and 0.85 to 0.99 in 2002). This suggests that bermuda had a greater ability to tolerate leaf desiccation before a visible decline in quality occurred. Sinclair and Ludlow (1985) proposed that LRWC was a good indicator of water status. Optimum LRWC is about $85 \%$ to $95 \%$ when water uptake by roots equals leaf transpirational water loss; the critical LRWC varies with species and tissue type, but is about $50 \%$. Below this level, physiological malfunctions occur, and death results (Taiz and Zeiger, 1998). Reduction in leaf water content results in reduced photosynthetic competence in many plants (Baker, 1993) and can lead to a decline in tall fescue and zoysia canopy net photosynthesis (Fu, 2003).

Drought stress resulting from low levels of deficit irrigation may cause dysfunction of leaf cellular membranes, resulting in an increased permeability for electrolytes. Greater membrane injury, and EL, occurred faster in all grasses at the lower irrigation levels (Figs. 5 and 6). Higher summer temperatures resulted in an increase in EL in all grasses, even those irrigated at $100 \%$ $\mathrm{ET}_{\mathrm{a}}$, particularly in 2001. The present study indicated that turf quality was acceptable until leaf EL increased to $22 \%$ for bluegrass, $24 \%$ for tall fescue, $38 \%$ for bermuda, and $26 \%$ for zoysia $\left(R^{2}\right.$ ranging from 0.88 to 0.99 in 2001 and 0.90 to 0.97 in 2002), suggesting that membranes of cells in bermuda were least affected by low levels of deficit irrigation.

In summary, these tests indicated that turfgrasses requiring the least water to maintain quality between June and September were 'Midlawn' bermuda and 'Rebel II' tall fescue. Tall fescue had lower water requirements than 'Meyer' zoysia the first year, but similar require- ments the second (assuming the turf manager could tolerate one week of unacceptable quality). Combinations of heat, and bluegrass billbug infestation, and deficit irrigation stress resulted in poor bluegrass performance under the conditions of this test. Physiological measurements indicated that bermuda was able to tolerate a lower LRWC and higher level of EL before quality declined to an unacceptable level.

\section{Literature Cited}

Aronson, L.J., A.J. Gold, and R.J. Hull. 1987. Cool-season turfgrass response to drought stress. Crop Sci. 27:1261-1266.

Baker, N.R. 1993. Light-use efficiency and photoinhibition of photosynthesis in plants underenvironmental stress, $p$. 221-235. In: J.A.C. Smith and H. Griffiths (eds.). Water deficits-Plant response from cell to community. Bios Scientific Publ., Oxford, U.K.

Carrow, R.N. 1995. Drought resistance aspects of turfgrasses in the southeast: ET and crop coefficients. Crop Sci. 35:1685-1690.

Dean,D.E.,D.A.Devitt,L.S. Verchick, and R.L.Morris. 1996. Turfgrass quality, growth, and wateruse as influenced by salinity and water stress. Agron. J. 88:844-849.

Ervin,E.H. and A.J. Koski. 1998. Drought avoidance aspects and crop coefficients of kentuckybluegrass and tall fescue turfs in the semiarid west. Crop Sci. 38:788-795.

Feldhake, C.M., R.E. Danielson, and J.D. Butler. 1984 Turfgrass evapotranspiration. II. Responses to deficit irrigation. Agron. J. 76:85-89.

Fry, J.D. and J.D. Butler. 1989. Response of tall and hard fescue to deficit irrigation. Crop Sci. 29:1536-1541.

Fu, J. 2003. Growth and physiological responses of turfgrasses to deficit irrigation. PhD diss. Kans. State Univ., Manhattan.

Fu, J. and B. Huang. 2001. Involvement of antioxidants and lipid peroxidation in the adaptation of two cool-season grasses to localized drought stress. Environ. Expt. Bot. 45:105-114.

Garrot,D.J. and C.F. Mancino. 1994. Consumptive wateruse of three intensively managed bermudagrasses growing under arid conditions. Crop Sci. 34:215-221.

Gibeault, V.A., J.L. Meyer, V.B. Youngner, and S.T. Cockerham. 1985. Irrigation of turfgrass below replacement of evapotranspiration as a means of water conservation: Performance of commonly used turfgrasses, $p$. 347-356. In: F. Lemaire (ed.). Proc. 5th Intl. Turfgrass Res. Conf., Avignon, France. 1-5 July. INRA Publ., Versailles, France.

Huang, B. and J. Fu. 2001. Growth and physiological responses of tall fescue to surface soil drying. Intl.Turfgrass Soc. Res. J. 9:291-296.

Kirnak H. , C. Kaya, I. Tas, and D. Higgs. 2001. The influence of water deficit on vegetative growth, physiology, fruit yield and quality in eggplants. Bulg. J. Plant Physiol. 27:34-46.

Qian, Y.L. and J.D. Fry. 1997. Water relations and drought tolerance of four turfgrasses. J. Amer. Soc. Hort. Sci. 122:129-133.

Qian, Y.L, J.D. Fry, S.C. Wiest, and W.S. Upham. 1996. Estimating turfgrass evapotranspiration using atmometers and the Penman-Monteith model. Crop Sci. 36:699-704.

Qian, Y.L. and M.C. Engelke. 1999. Performance of five turfgrasses under linear gradient irrigation. HortScience 34:893-896.

Qian, Y.L., J.D. Fry, and W.S. Upham. 1997. Rooting and drought avoidance of warm-season turfgrasses and tall fescue in Kansas. Crop Sci 37:905-910.

Sheffer, K.M., J.H. Dunn, and D.D. Minner. 1987. Summer drought response and rooting depth of three cool-season turfgrasses. HortScience 22:296-297.

Sinclair, T.R. and M.M. Ludlow. 1985. Who taught plants thermodynamics? The unfulfilled potential of plant water potential. Austral. J. Plant Physiol. 33:213-217.

Statistical Analysis System. 1989. Version 6.12. SAS Inst, Cary, N.C.

Taiz,L. andE. Zeiger. 1998. Plant physiology. $2^{\text {nd }}$ ed. Sinauer Assoc., Sunderland, Mass. 